\title{
CORPORATE GOVERNANCE AND THE ABNORMAL RETURNS TO ACQUISITION ANNOUNCEMENTS
}

\author{
Mark Swanstrom \\ Northwestern State University \\ Natchitoches, LA
}

\begin{abstract}
This paper investigates the relationship between a firm 's corporate governance structure and the abnormal returns associated with acquisition announcements. Based on a sample of 294 acquisitions occurring from 1994 through 1998, it is found that acquiring firms have significant two-day abnormal returns of $-2.71 \%$. A multiple regression model that includes corporate governance variables has an Adjusted R-squared of $14.2 \%$ with board size, the sensitivity of the CEO's wealth to changes in share price, method of payment, and acquiring firm size all being significant explanatory variables.
\end{abstract}

The modern corporation is a complex organization of interlocking relationships. For publicly held companies, one of the most important relationships is between the owners and managers of the firm. This relationship is a classic example of the principal-agent relationship and is characterized by a potential misalignment of goals where the agent may behave in his own interest instead of acting in the principal's interest. A firm's corporate governance structure can be used to reduce the total agency costs of a firm through the monitoring of management actions and by aligning the managers' self-interests with those of shareholders.

The board of directors has the responsibility to represent shareholders by monitoring top management. They do this by hiring and firing management, designing the executive compensation contract, and voting on major firm decisions. However, recent events from Enron to WorldCom indicate that the board may not always adequately monitor management. These events have stirred calls for board reform and the effect of board structure on corporate decision making is an important and widely debated topic.

A firm's compensation policy should be designed to attract and retain quality managers and also to align the managers' incentives with shareholders. Executive compensation is primarily composed of a base salary, a bonus often tied to accounting returns, and equity-based incentives. Stock option grants are an increasingly important component of compensation and can align interests by making compensation and overall wealth more sensitive to shareholder performance.

This study investigates the relationship between corporate governance and agency costs by examining the abnormal returns to acquisition announcements. While there are a variety of explanations for acquisitions that increase share- 
holder wealth, many acquisitions actually reduce shareholder wealth in both the short-run and the long-run. One explanation is that shareholder wealth reducing acquisitions are the result of the failure of corporate governance mechanisms to properly align managers' interests with those of shareholders.

The following section of this paper reviews the literature on corporate governance and mergers. The third section presents the data and methodology, followed by the empirical results in the fourth section. The final section summarizes the findings with suggestions for further research.

\section{Literature Review}

The existing literature investigating the relationship between managers' interests and mergers examines the issue from varying perspectives. Morck, Shleifer, and Vishny (1990) test managerial self-interest indirectly by arguing that self-interested managers will either diversify or buy growth firms. Since these types of acquisitions were found to be more likely to reduce shareholder wealth, they concluded that they were driven by self-interest. Kroll, Simmons, and Wright (1990) found that $\mathrm{CEO}$ compensation increased following acquisitions due in part to the increased size of the firm. CEO shareholdings and incentive plans were found to be positively related to announcement cumulative abnormal returns (CARs) by Travlos and Waegelein (1992). Ueng (1998) also found that managers with large stockholdings relative to salary are more likely to make acquisitions that increase shareholder wealth. Datta, Iskandar-Datta, and Raman (2001) find that the proportion of equity-based compensation (EBC) leads to higher abnormal returns in mergers. All of these papers support the idea that managers may behave in their own interest in merger decisions as opposed to focusing on shareholders' interest.

This paper differs in that it tries to take a broader perspective of corporate governance. If the corporate governance structure is effective, then the manager is less likely to make shareholder-wealth reducing decisions, including acquisitions. However, the question arises as to what factors affect governance effectiveness. The variables used in this study include the proportion of the board represented by independent outsiders, the size of the board of directors, and the sensitivity of the CEO's equity-based wealth to stock price.

The role of the board of directors in modern corporations has become increasingly important in recent years. Critics have pointed to scandals at Enron, WorldCom, and Tyco (just to name a few) as evidence that boards have become too lax in their duties and simply rubberstamp the actions of CEOs. These failures of corporate governance have opened the door to government involvement such as Sarbanes-Oxley or Eliot Spitzer. While there have been many suggestions for board reform, reducing board size and increasing board independence are two of the most common and tested recommendations.

Fama (1980) and Fama and Jensen (1983) recommend the use of independent outsiders on the board of directors. As support, Weisbach (1988) finds that the relationship between executive turnover and performance is stronger for outsider- 
dominated boards. Byrd and Hickman (1992) find that tender offer bidders are best served when outsider representation is close to $60 \%$ of the board. Rosenstein and Wyatt $(1990,1997)$ find that the share price response was positive to announcements of outside directors and insignificantly negative to the addition of inside directors. Thus, there is some empirical evidence that supports the argument that outside representation on the board might result in better monitoring. This leads to the first hypothesis of this paper stated in null form.

\section{Hypothesis 1: Acquisition abnormal returns are unrelated to the propor- tion of outside directors.}

Board size has also been suggested as a possible factor affecting monitoring quality by Lipton and Lorsch (1992) and Jensen (1993). Yermack (1996) finds that the log of board size is negatively related to Tobin's Q. Core, Holthausen, and Larcker (1999) find that CEOs are able to extract greater pay from larger boards. However, there is also evidence that large boards do a better job. Grinstein and Hribar (2004) find that larger boards tend to pay smaller M\&A bonuses to managers. The effect of board size then becomes an empirical question tested in the second hypothesis.

\section{Hypothesis 2: Acquisition abnormal returns are unrelated to board size.}

While the structure of the board is part of corporate governance, one must also examine what the board does. One of the most important functions of the board is determining the compensation of executives and the degree to which a manager's wealth is tied to shareholder wealth. While setting compensation is not the only monitoring function of the board, it is a function that has been criticized as an example of CEOs having excess influence over the board. Other monitoring functions might involve the threat of firing managers for inferior performance and the level of effort put forth by outside directors in evaluating firm decisions, including mergers; however, these functions cannot be observed and measured as easily as the compensation sensitivity.

Jensen and Murphy (1990), among others, argue that compensation is not effectively related to share performance for many firms. Baker, Jensen, and Murphy (1988) and Rose and Shepard (1997) show that factors such as firm size and degree of diversification also affect compensation levels. Thus, a manager might be better off if an acquisition increases size and/or diversification even if shareholder wealth is reduced.

Since compensation structure may change dramatically from year to year, the use of a single year's compensation may not capture the true alignment between the manager's wealth and shareholder wealth. To better capture this, a measure of the sensitivity of the CEO's total firm-related wealth to changes in share price is included. If abnormal returns to acquisitions are positively related to the 
sensitivity of the CEO's total wealth to changes in share price, then this would provide evidence that greater wealth sensitivity results in better alignment between managers and shareholders as tested in the third hypothesis.

Hypothesis 3: Acquisition abnormal returns are unrelated to the sensitivity of the CEO's total wealth to changes in share price.

These hypotheses investigate agency conflict within firms by examining its effect on acquisition decisions. In addition to the above variables, control variables representing whether the acquisition was made with cash and the size of the acquiring firm are also included. These variables have been found to be related to merger returns and are included to isolate the effects of the tested variables.

\section{Data and Methodology}

This study basically involves a two-step procedure. First, an event study on acquisition announcements is used to determine the acquiring firm's abnormal returns. Second, these abnormal returns are used as the dependent variable in regression models in order to explain the cross-sectional variation in abnormal returns.

The sample includes 294 acquisitions that were completed from 1994 to 1998. In order to be included in the sample, the acquisition could not involve regulated utility or financial firms, foreign firms, or privately-held firms. Sufficient data for the companies also had to be available from CRSP, Compustat, and proxy statements. In order to reduce the level of noise in the findings, the target firm had to have a market value of at least $10 \%$ of the acquiring firm, there could not be a preexisting relationship between the firms, the acquiring firm could not have made an earlier acquisitions in the same fiscal year, and there could be no confounding events around the two-day event window. Table 1 summarizes the sample selection process and reasons for exclusion.

\section{Table 1 \\ Sample Selection Summary}

2,173 Firms delisted from CRSP due to acquisition from 1994-1998

1,006 Regulated utility (4000's) or financial (6000's) firms

435 Acquiring firm common stock data not on CRSP

319 Market value of target firm less than $10 \%$ of value of acquiring firm

43 Preexisting relationship between firms

43 Missing other data from proxies or Compustat

14 Acquiring firm had prior acquisition in same fiscal year

19 Confounding announcement around two-day event window

294 Final Sample of acquisitions for two-day event window 
The market model approach was used to calculate abnormal returns to acquiring firm shareholders. The parameters for the model are estimated from day -135 to day -16 , where day 0 is the first newspaper report of the acquisition. The initial announcement date was determined by searching the Lexis/Nexis database and the Wall Street Journal index. The CRSP equal-weighted index is used as a proxy for the market return.

$\mathrm{R}_{\mathrm{jt}}=\alpha_{\mathrm{j}}+\beta_{\mathrm{j}} \mathrm{R}_{\mathrm{mt}}+\varepsilon_{\mathrm{jt}}$

The estimated parameters are then used to determine a security's expected return given the market return. The expected return is then subtracted from the security's actual return to determine the abnormal return for each day in the event window.

$$
A R_{j t}=R_{j t}-\left(\alpha_{j}+\beta_{j} R_{m t}\right)
$$

The cumulative abnormal return for a given security is simply the sum of daily abnormal returns over the event window.

$\mathrm{CAR}_{\mathrm{j}}=\Sigma \mathrm{AR}_{\mathrm{jt}}$

The CARs are then used as the dependent variable in a regression model using corporate governance variables as independent variables.

For each acquiring firm in the sample, the proxy statement for the fiscal yearend preceding the first announcement of the merger is collected. The number of directors is found and directors are classified as being independent if they have never been employed by the firm nor had any other outside business dealings with the firm such as being employed as the firm's lawyer, accountant, banker, or consultant. Executives of other firms that do business with the acquiring firm are treated as being affiliated. Cross directorships, where the director of the acquiring firm is a CEO of a firm that has the CEO of the target firm as a director, are also treated as being affiliated. The independent variables used are defined as the number of outside, unaffiliated, independent directors divided by the total number of directors (OUTDIR) and the natural $\log$ of the number of directors (BRDSIZ).

Another independent variable measures the sensitivity of the CEO's firm-related wealth to changes in the firm's stock price (WTHSEN). The proxy statement lists the number of shares owned, the number and intrinsic value of exercisable stock options, the number and intrinsic value of unexercisable stock options, and the number and exercise price of stock options granted in the past year. This data is provided for the firm's top five managers, but only the data for the CEO at the time when the merger is announced is used.

Valuing executive stock options and their delta sensitivity to changes in stock price is a difficult process. Since these options are non-tradeable, an option pric- 
ing model has to be used. The Merton modification of the Black-Scholes option pricing model is used to value the stock options.

$C=e^{-\delta t} S^{*} N(d 1)-X e^{-r t * N}(d 2)$

The stock prices are taken as of the fiscal year-end preceding the merger announcement. The exercise price for new grants is given in the proxy statement, but the weighted average exercise price for old grants must be estimated. First, the intrinsic value of the new grants is calculated as the difference between the fiscal-year end price and the exercise price multiplied by the number of new option grants. If the fiscal year end price is less than the exercise price, then the intrinsic value is zero.

$(\mathrm{S}-\mathrm{X}) *$ Number of new grants $=$ Intrinsic Value of new grants

Second, this value is deducted from the total intrinsic value of all option grants as given in the proxy statement leaving the intrinsic value of the old option grants.

To find the number of old option grants, simply deduct the number of new grants from the total number of grants as reported in the proxy statement. Finally, the weighted average exercise price for old option grants can be estimated by solving for $X$ using the following formula.

$(\mathrm{S}-\mathrm{X}) *$ Number of old grants $=$ Intrinsic Value of old grants

The return of the continuously compounded 10-year and 5-year CRSP US Government Bond Fixed Term Index Series is used to estimate the risk-free rate of interest, $r$. The time to expiration, $t$, is assumed to be 10 years for new grants and 5 years for existing grants. Finally, $e$ is the base of the natural logarithms and $N\left(^{*}\right)$ is the cumulative probabilities for the following unit normal variables:

$d 1=\frac{\ln \left(\frac{S}{X}\right)+t\left[\mathrm{r}-\delta+\left(\frac{\sigma^{2}}{2}\right)\right]}{\alpha \sqrt{ } t}$

$d 2=\frac{\ln \left(\frac{S}{X}\right)+t\left[\mathrm{r}-\delta+\left(\frac{\sigma^{2}}{2}\right)\right]}{\alpha \sqrt{ } t}$

Where $\delta$ represents a constant dividend yield gathered from Compustat for the fiscal year prior to the merger announcement and $\sigma$ is the standard deviation of the stock's return calculated during the market model estimation period discussed earlier. 
By summing the value of the stock held by the CEO, the value of the new grants, and the value of prior grants, we can estimate the CEO's total wealth related to the value of the firm's stock. The CEO will likely have some of his wealth invested in other assets, and while this may have some effect through the correlation between the value of the firm and the value of the CEO's other assets, this effect is believed to be small enough to allow it to be ignored.

The CEO's wealth sensitivity is then calculated as the change in the CEO's firm-related wealth given a $1 \%$ change in the stock price scaled by the CEO's total firm-related wealth (WTHSEN). Guay (1999) suggests that the sensitivity of compensation and wealth is more likely to affect decision making than just the level of wealth. By using the valuation models, it is possible to calculate the change in value for a given $1 \%$ change in the firm's stock price. For stock this is an obvious calculation --- a $1 \%$ change in the firm's stock price will change the value of the CEO's stock holdings by $1 \%$. However, option values are more sensitive to changes in share price, and greater option holdings relative to stock holdings will increase the wealth sensitivity measure.

In addition to the test variables described above, an indicator variable identifying primarily cash transactions (CSHPMT) and the natural log of the market value of the acquiring firm (LOGSIZ) measured sixteen days prior to the merger announcement are included. These control variables have been found to be significant explanatory variables in previous studies. Other variables that have been found to be significant, such as premium paid and whether or not the target firm is in the same industry, are not included. The reasoning for this is that their inclusion distracts from the purpose of this study and ultimately leads to the same questions. For example, if high takeover premiums tend to have lower abnormal returns, why would the acquiring firm and its managers be willing to pay such high premiums?

\section{Empirical Results}

In this section, the empirical results of the event study on acquisition announcements and hypotheses tested are given. Table 2 contains descriptive statistics on the model parameters, abnormal returns for each day in the event window, and the cumulative abnormal returns (CARs). Two-day abnormal returns on acquisition announcements averaged $-2.71 \%$ and ranged from a high of $19.72 \%$ to a low of $-32.38 \%$. The mean abnormal returns on days -1 and 0 are $-1.27 \%$ and $-1.44 \%$, respectively. The mean CAR and both daily abnormal returns are significantly different from zero at the $1 \%$ level and are consistent with prior findings of negative returns to acquirers.

The next part of the study takes the CAR's for each acquiring firm and uses them as the dependent variable in a regression model. Table 3 contains summary statistics of the independent variables, Table 4 shows the correlations between the independent variables, and Table 5 shows the regression results. 
Table 2

Summary Statistics of Event Study Abnormal Returns

\begin{tabular}{llllll} 
& Mean & Median & St. Dev. & Max & Min \\
\hline Alpha & -0.0003 & -0.0003 & 0.0026 & 0.0094 & -0.0099 \\
Beta & 1.3900 & 1.2426 & 0.9109 & 4.6280 & -0.5371 \\
CAR $(-1,0)$ & $-0.0271^{* * *}$ & -0.0222 & 0.0748 & 0.1972 & -0.3238 \\
Day -1 & $-0.0127^{* * *}$ & -0.0095 & 0.0565 & 0.2186 & -0.1986 \\
Day 0 & $-0.0144^{* * *}$ & -0.0085 & 0.0504 & 0.1298 & -0.2938 \\
\hline
\end{tabular}

Tests for significant differences from zero were conducted for the CAR and the daily abnormal returns. Significance at the $10 \%, 5 \%$, and $1 \%$ levels are indicated by '*', '**, and '***', respectively.

Table 3

\section{Summary Statistics of Independent Variables}

\begin{tabular}{lccccc} 
& Mean & Median & St. Dev & Min & Max \\
\hline OUTDIR & 0.529 & 0.556 & 0.193 & 0 & 0.900 \\
BRDSIZ & 2.064 & 2.079 & 0.322 & 1.099 & 2.833 \\
WTHSEN & 0.012 & 0.011 & 0.002 & 0.010 & 0.019 \\
CSHPMT & 0.299 & 0 & 0.459 & 0 & 1 \\
LOGSIZ & 20.207 & 20.282 & 1.615 & 16.525 & 24.533 \\
\hline
\end{tabular}

For all tables, OUTDIR is the proportion of unaffiliated outsiders on the board of directors. BRDSIZ is the natural log of the number of directors on the board. WTHSEN is the percentage change in the value of the CEO's total firm-related wealth given a 1\% increase in the firm's FYE share price. CSHPMT is a dummy variable equal to one if the acquisition was financed by cash. LOGSIZ is the natural log of the market value of the acquirer measured 16 days prior to the acquisition announcement.

Table 4

\section{Correlations Among Independent Variables}

\begin{tabular}{lccccc} 
VARIABLE & OUTDIR & BRDSIZ & WTHSEN & CSHPMT & LOGSIZ \\
\hline OUTDIR & 1.0000 & 0.1163 & 0.2361 & 0.1274 & 0.1464 \\
BRDSIZ & 0.1163 & 1.0000 & 0.3258 & 0.2607 & 0.4691 \\
WTHSEN & 0.2361 & 0.3258 & 1.0000 & 0.2443 & 0.3740 \\
CSHPMT & 0.1274 & 0.2607 & 0.2443 & 1.0000 & 0.0573 \\
LOGSIZ & 0.1464 & 0.4691 & 0.3740 & 0.0573 & 1.0000 \\
\hline
\end{tabular}


Table 5

OLS Multiple Regression Results

Model 1

Model 2

Model 3

\begin{tabular}{lccc}
\hline OUTDIR & -0.026 & & \\
& -1.209 & & \\
BRDSIZ & 0.051 & & \\
& $3.416^{* * *}$ & & \\
WTHSEN & 8.803 & 3.373 & $3.915^{* * *}$ \\
& $3.337^{* * *}$ & 0.038 & \\
CSHPMT & 0.031 & $4.042^{* * * *}$ & \\
& $3.296^{* * *}$ & -0.006 & \\
LOGSIZ & -0.010 & $-2.323^{* *}$ & \\
& $-3.485^{* * *}$ & 0.109 & 0.047 \\
\hline Adj. R-SQ & 0.142 & $12.962^{* * *}$ & $15.329^{* * *}$ \\
F-Stat. & $10.700^{* * *}$ & & \\
\hline
\end{tabular}

Results represent a single regression of the form $\operatorname{CAR}(-1,0)_{i}=\beta_{0}+\beta_{1} X 1_{i}+\beta_{2} X 2_{i}+\ldots+\beta_{5} X 5_{i}+\varepsilon_{i}$ Where $X$ is the variable of interest. OLS estimates of each $\beta$ are given along with the t-statistic for testing the null hypothesis of $\beta=0$. Adjusted R-Squared's and F-statistics for testing the null hypothesis of $\beta_{1}=\beta_{2}=\ldots=\beta_{5}=0$ are given at the bottom. Significance at the $10 \%, 5 \%$, and $1 \%$ levels are indicated by '*', '**, and '***', respectively, using two-tailed tests.

While there is some correlation among the independent variables, the strongest correlations are between the test variables and the firm size control variable. Firm size and board size are highly correlated, but it is important that both variables remain in the model as we want to capture the effect that board size has that is independent from the effect of firm size. As seen in Table 5, these two variables actually have opposite effects on abnormal returns.

The overall model is highly significant with an F-value of 10.7 and an Adjusted $\mathrm{R}$-squared of $14.2 \%$. Among the independent variables, wealth sensitivity, board size, method of payment, and acquiring firm size are all significant at the $1 \%$ level. The wealth sensitivity measure was positive and significant as expected, but the strength of the relationship warrants some attention. In a similar study, Datta, Iskandar-Datta, and Raman (2001) regress two-day abnormal returns on a measure of equity-based compensation (EBC) along with acquiring firm size and a dummy variable for cash acquisitions. Their Model 1 shows a significant, positive relationship between EBC and abnormal returns and the model has an Adjusted R-squared of $1.25 \%$ and an F-statistic of 2.45. Using Wealth Sensitivity instead of EBC in this study results in Model 2 with an Adjusted R-squared of $10.9 \%$ and an F-statistic of 12.96 . Using just Wealth Sensitivity by itself in 
a simple regression results in an Adjusted R-squared of $4.7 \%$ and an F-statistic of 15.33 for Model 3. These results suggest the importance of the CEOs overall wealth as opposed to just examining a single year's compensation as motivation to the acquisition decision.

Independent outside directors made up an average of $52.9 \%$ of the boards for this sample of firms. This proportion is somewhat higher than the $39.2 \%$ mean figure found in Byrd and Hickman (1992), but is similar to the $56 \%$ found in Shivdasani (1993). The regression results in Table 5 indicate that the proportion of outside directors on the board is not a significant predictor of abnormal returns.

This result is in contrast to Byrd and Hickman's (1992) finding of a positive but nonlinear relationship in their study of abnormal returns to tender offers where the acquiring firm is listed on the NYSE or AMEX. However, when Byrd and Hickman use proportion of independent directors as their variable, they also find no significance. They do find a positive, significant relationship when they use a dummy variable for boards with greater than $50 \%$ independent directors. When they use a piecewise regression, they find a positive and significant relationship when independent directors make up $40-60 \%$ of the board and a negatively significant relationship for boards with greater than $60 \%$ independent board members. In an effort to further investigate the difference in the results, the CARs are calculated for different proportions of outside representation and are presented in Table 6 . The results provide no evidence of a relation between outside directors and abnormal returns, and regressions that include a dummy for independent boards and piecewise regressions also yield no significant results.

Table 6

Outside Directors and Cumulative Abnormal Returns

\begin{tabular}{lcc} 
VARIABLE & Occurrences & CAR \\
\hline OUTDIR less than $40 \%$ & 71 & $-2.09 \%$ \\
OUTDIR 40\% to $50 \%$ & 71 & $-2.96 \%$ \\
OUTDIR 50\% to $67 \%$ & 87 & $-3.02 \%$ \\
OUTDIR over $67 \%$ & 65 & $-2.70 \%$ \\
\hline
\end{tabular}

The average board size for the firms in this sample is 8.31 directors (average $\log$ of board size is 2.064). This figure is considerably lower than the 12.1 directors in Byrd and Hickman (1992) based on a sample of NYSE/AMEX firms and the 12.25 directors in Yermack (1996) based on a sample from the Forbes 500 list of largest U.S. public corporations. However, the figure is more in line with the 9.35 directors found in Denis, Denis, and Sarin (1999) who used a random sample of all firms covered by CRSP.

Based on the regression results, it is possible to reject the null hypothesis of no relation between board size and abnormal returns at the $1 \%$ significance 
level suggesting that larger boards do a better job of monitoring firm managers in acquisition decisions. The positive finding between board size and abnormal returns goes against suggestions that large boards are less effective at monitoring made by Lipton and Lorsch (1992) and Jensen (1993). However, the empirical evidence on this matter was somewhat mixed and warrants additional investigation. Table 7 shows the average CARs for different board sizes. While this shows some evidence of a decline for boards of 12 or more, the greater evidence is that small boards do a poor job.

\section{Table 7}

Board Size and Cumulative Abnormal Returns

\begin{tabular}{|c|c|c|c|}
\hline \multicolumn{2}{|c|}{ VARIABLE } & \multirow{2}{*}{$\frac{\text { Occurrences }}{45}$} & \multirow{2}{*}{$\frac{\text { CAR }}{-6.10 \%}$} \\
\hline BRDSIZ & less than 5 & & \\
\hline BRDSIZ & equals 6 & 36 & $-3.70 \%$ \\
\hline BRDSIZ & equals 7 & 56 & $-2.90 \%$ \\
\hline BRDSIZ & equals 8 & 31 & $-2.70 \%$ \\
\hline BRDSIZ & equals 9 & 38 & $-2.80 \%$ \\
\hline BRDSIZ & equals 10 & 24 & $-1.80 \%$ \\
\hline BRDSIZ & equals 11 & 24 & $1.10 \%$ \\
\hline BRDSIZ & equals 12 & 23 & $-0.15 \%$ \\
\hline BRDSIZ & more than 12 & 19 & $-1.12 \%$ \\
\hline
\end{tabular}

The two results involving the board of directors differ from some previous findings, but there are some possible interpretations and explanations. First, this sample is considerably different from previous studies. Most previous studies focused on large firms by sampling from NYSE/AMEX firms, Forbes 500 firms, or firms with data on S\&P's Execucomp. In a more recent article covering mergers between 1993 and 1999, Grinstein and Hribar (2004) also find evidence against the superiority of smaller boards in their analysis of M\&A bonuses. They speculate that the differences in their findings might be due to a greater proportion of new-economy firms. This might also be the case here, although it is uncertain why new-economy boards would behave differently from old-economy boards.

A second possibility involves the different dependent variables used in the studies. Yermack (1996) found a negative relationship between board size and Tobin's $Q$, whereas I find a positive relationship between board size and acquisition announcement CARs. Theoretically, Tobin's $Q$ should reflect the market's estimate of the present value of all of a firm's future investment opportunities, including acquisitions. Under this idea, the different findings might reflect the market's high expectations of firms with small board sizes and independent boards and the market's subsequent disappointment when the acquisition is announced. 
A third possibility is the different roles taken by the board of directors. In studies of CEO turnover, both Yermack (1996) and Wu (2000) find that the relationship between turnover and performance is stronger for firms with smaller boards. In turnover decisions, it seems reasonable that greater independence between the board and the CEO would benefit shareholders. However, in acquisition decisions, shareholders might be better served by a closer relationship between the board and the CEO. Larger boards might contribute additional knowledge about the target firm and the industry overall. This distinction between the monitoring and advisory roles might explain why larger boards seemed to perform better in this paper and in Grinstein and Hribar (2004).

The cash payment and firm size control variables are both significant explanatory variables in the model. Thirty percent of the acquisitions are financed by cash and there is a positive relation with the CARs that is significant at the $1 \%$ level. This is consistent with findings that stock swaps are viewed less favorably by the market. The average size of acquiring firms is $\$ 2.2$ billion (average log of firm size is 20.2) and there is a negative relation that is significant at the $1 \%$ level suggesting that large firms make worse acquisition decisions.

In order to evaluate any possible changes in the variables over time, Table 8 presents the mean variable values for the mergers announced in the different years from 1993 through 1998 . There does not appear to be any obvious trends in the data and a regression model that includes dummy variables for the years in addition to the existing variables does not yield any relevant insights.

Table 8

Variable Averages for Different Years

\begin{tabular}{llllll} 
YEAR & $\mathbf{1 9 9 3 / 9 4}$ & $\mathbf{1 9 9 5}$ & $\mathbf{1 9 9 6}$ & $\mathbf{1 9 9 7}$ & \multicolumn{1}{c}{$\mathbf{1 9 9 8}$} \\
\hline OCCURRENCES & \multicolumn{1}{l}{39} & \multicolumn{1}{l}{46} & \multicolumn{1}{l}{58} & \multicolumn{1}{l}{92} & \multicolumn{1}{l}{59} \\
CAR(-1,0) & -0.0280 & -0.0411 & 0.0043 & -0.0226 & -0.0534 \\
OUTDIR & 0.5139 & 0.5454 & 0.5220 & 0.5119 & 0.5582 \\
BRDSIZ & 2.1125 & 2.0972 & 2.1510 & 2.0171 & 1.9961 \\
WTHSEN & 0.0117 & 0.0118 & 0.0119 & 0.0113 & 0.0116 \\
CSHPMT & 0.2564 & 0.3043 & 0.3966 & 0.2609 & 0.2881 \\
LOGSIZ & 20.3054 & 20.0858 & 20.2856 & 20.0390 & 20.4232 \\
\hline
\end{tabular}

\section{Conclusion}

The first contribution of this paper is simply the use of data from the 1990's and the inclusion of smaller, new-economy firms in the sample. Holmstrom and Kaplan (2001) contrast merger activity in the 1980's and 1990's and suggest that improved corporate governance has made the 1990's much less hostile. They 
note the rise in equity-based compensation to top executives and a 1993 change in tax laws that encouraged the use of incentive compensation as evidence that firm managers are more responsive to shareholders. They also mention improved monitoring as evidenced by a decline in board sizes and increased shareholder activism by CalPERS and other institutions.

While corporate governance may have resulted in a less hostile market for corporate control, this has not translated into improved returns to acquiring firms. I find two-day abnormal returns of $-2.71 \%$ when acquisitions are announced. If corporate governance has improved in the 1990's, why are firms still making acquisitions that reduce shareholder wealth?

The most interesting finding in this paper is the strength of the relationship between CEO's wealth sensitivity and acquisition announcement CARs. The other two findings add to the muddled results regarding boards of directors and firm performance. In a survey article, Hermalin and Weisbach (2003) conclude that the relationship between board charcteristics and firm performance may be spurious as both may be driven by other factors. The results in this paper agree that board composition is not a determining factor and that smaller boards may not be the cure imagined.

\section{References}

Baker, G., Jensen, M., \& Murphy, K. (1988). Compensation and incentives: Practice vs. theory. Journal of Finance, 43, 593-616.

Byrd, J. W. \& Hickman, K. A. (1992). Do outside directors monitor managers? Journal of Financial Economics, 32, 195-221.

Core, J., Holthausen, R., \& Larcker, D. (1999). Corporate governance, chief executive officer compensation, and firm performance. Journal of Financial Economics. 51, $371-406$.

Datta, S., Iskandar-Datta, M., \& Raman, K. (2001). Executive compensation and corporate acquisition decisions. Journal of Finance, 56, 2299-2336.

Denis, D., Denis, D., \& Sarin, A. (1997). Ownership structure and top executive turnover. Journal of Financial Economics, 45, 193-221.

Fama, E. (1980). Agency problems and the theory of the firm. Journal of Political Economy, 88, 288-307.

Fama, E. \& Jensen, M. (1983). Separation of ownership and control. Journal of Law and Economics, 26, 301-325.

Grinstein, Y. \& Hribar, P. (2004). CEO compensation and incentives - Evidence from M\&A bonuses. Journal of Financial Economics, 73, 119-143. 
Guay, W. (1999). The sensitivity of CEO wealth to equity risk: An analysis of the magnitude and determinants. Journal of Financial Economics, 53, 43-71.

Hermalin, B. \& Weisbach, M. (2003). Boards of directors as an endogenously determined institution: A survey of the economic literature, Economic Policy Review, 9 (1), 726.

Holmstrom, B. \& Kaplan, S. (2001). Corporate governance and merger activity in the U.S.: Making sense of the 1980s and 1990s. MIT Dept. of Economics Working Paper No. 01-11. Retrieved June 10, 2001, from SSRN database.

Jensen, M. (1993). The modern industrial revolution, exit, and the failure of internal control systems. Journal of Finance, 48, 831-880.

Jensen, M. \& Murphy, K. (1990). Performance pay and top-management incentives. Journal of Political Economy, 88, 225-264.

Kroll, M., Simmons, S., \& Wright, P. (1990). Determinants of chief executive officer compensation following major acquisitions. Journal of Business Research, 20, 349-366.

Lipton, M. \& Lorsch, J. (1992). A modest proposal for improved corporate governance. The Business Lawyer, 48, 59-77.

Morck, R., Shleifer, A., \& Vishny, R. (1990). Do managerial objectives drive bad acquisitions? Journal of Finance, 45, 31-48.

Rose, N. \& Shepard, A. (1997). Firm diversification and CEO compensation: Managerial ability or executive entrenchment? RAND Journal of Economics, 28, 489-514.

Rosenstein, S. \& Wyatt, J. (1990). Outside directors, board independence, and shareholder wealth. Journal of Financial Economics, 26, 175-192.

Rosenstein, S. \& Wyatt, J. (1997). Inside directors, board effectiveness, and shareholder wealth. Journal of Financial Economics, 44, 229-250.

Shivdasani, A. (1993). Board composition, ownership structure, and hostile takeovers. Journal of Accounting and Economics, 16, 167-198.

Travlos, N. \& Waegelein, J. (1992). Executive compensation, method of payment, and abnormal returns to bidding firms at takeover announcements. Managerial and Decision Economics, 13, 493-501.

Ueng, $J$. (1998). Manager incentive and returns to shareholders of acquiring firms. Review of Business, 19, 27-30.

Weisbach, M. (1988). Outside directors and CEO turnover. Journal of Financial Economics, 20, 431-460. 
Wu, Y. (2000). Honey, CalPERS shrunk the board! Retrieved June 10, 2001, from SSRN database.

Yermack, D. (1996). Higher market valuation of companies with a small board of directors. Joumal of Financial Economics, 40, 185-211.

Mark Swanstrom is Assistant Professor of Finance at Northwestern State University of Louisiana. His research interest is in corporate governance, mergers and acquisitions, and international investments. 
